\title{
PENGARUH BUNGA DEPOSITO, KURS MATA UANG, DAN HARGA EMAS TERHADAP INDEKS HARGA SAHAM GABUNGAN (IHSG)
}

\author{
Guntur Irianto ${ }^{1}$
}

\begin{abstract}
Article explores the effects of rate, rupiah, and US dollar kurs, and gold price to the IHSG by using a linier double regression model. It is concluded that deposit rate, rupiah and US dollar have a significant negatif effect to IHSG. Those two variables have interrelated substations to the exchange; otherwise the gold price had a posite effect to IHSG (EH).
\end{abstract}

Keywords: deposit rate, currency rate, gold price, IHSG

\section{ABSTRAK}

Tujuan artikel ini mengetahui pengaruh suku bunga, kurs rupiah, dan dolar Amerika, serta harga emas terhadap IHSG di Bursa Efek Jakarta dengan model regresi berganda linier. Hasil penelitian menunjukan bahwa bunga deposito kurs Rp/US\$ berpengaruh negatif secara signifikan terhadap IHSG. Kedua variabel tersebut memiliki hubungan yang saling subtitusi dengan dengan bursa efek sedangkan harga emas berpengaruh positif terhadap IHSG.

Kata kunci: bunga deposito, kurs mata uang, bunga, emas, IHSG

\footnotetext{
${ }^{1}$ Staf Pengajar UPN Veteran, UNSN, dan UBiNus, Jakarta
} 


\section{PENDAHULUAN}

Alternatif investasi dapat berupa investasi pada (1) aktiva riil yang secara umum melibatkan aset nyata seperti membeli properti/rumah, mesin atau pabrik, menyimpan emas atau; (2) investasi finansial seperti membeli sertifikat deposito, commercial paper, saham, dan membeli obligasi. Masing-masing alternatif mempunyai kelebihan dan kekurangan.

Salah satu bentuk investasi finansial yang diminati oleh masyarakat adalah investasi kepemilikan saham melalui pasar modal. Hasil (return) yang diharapkan oleh pemegang saham adalah pembagian dividen dan capital gain. Dividen merupakan pembagian keuntungan kepada pemegang saham yang besarnya tergantung dari kebijakan dividen (dividen policy) masingmasing perusahaan. Capital gain adalah keuntungan yang diperoleh karena harga jual saham lebih tinggi dari harga belinya. Namun, tidak semua saham memberikan dividen dan capital gain. Suatu perusahaan mungkin saja tidak dapat membagikan dividen pada tahun yang berjalan karena adanya kerugian atau kebijakan investasi. Hal itu berlaku pula pada saham yang menimbulkan capital loss (kerugian) karena harga jualnya lebih rendah daripada harga belinya.

Bentuk investasi di pasar modal yang lain adalah membeli obligasi. Obligasi pada dasarnya merupakan bukti utang pihak yang menerbitkan obligasi kepada pemegang obligasi selama umur obligasi. Pihak pemegang obligasi sebagai pihak yang meminjamkan uang berhak mendapatkan imbalan berupa kupon yang nilainya tetap dan dinyatakan dalam persentase dari nilai nominal obligasi. Kupon harus dibayarkan sesuai perjanjian dan tidak terkait bila perusahaan penerbit obligasi mengalami keuntungan atau kerugian dalam bisnisnya.

Uraian itu menggambarkan bahwa saham tidak memberikan kepastian hasil (return). Karena tidak ada kepastian return tersebut, saham tergolong investasi yang berisiko (risky asset). Sebaliknya, obligasi memberikan kepatian return sehingga disebut investasi bebas resiko (riskfree asset). Oleh karena itu, investasi dalam saham memerlukan pertimbangan yang lebih cermat dibandingkan investasi dalam obligasi.

Masalah yang dihadapi oleh masyarakat selaku investor pada saham adalah sulit melakukan prediksi harga saham yang selalu berfluktuasi dari detik ke detik. Dengan demikian, diperlukan strategi investasi mulai dari kebijakan investasi sampai evaluasi kinerja. Menurut Suad Husnan (1998) terdapat lima langkah strategi investasi, yaitu (1) menentukan kebijakan investasi; (2) analisis sekuritas; (3) pembentukan portfolio; (4) melakukan revisi portfolio; (5) evaluasi kerja portfolio.

Kelima langkah itu sangat dipengaruhi public information karena paling mudah diperoleh masyarakat. Dengan informasi itu, masyarakat dapat mengambil keputusan terhadap investasinya di pasar modal. Informasi yang bersifat public information antara lain tingkat suku bunga, kurs rupiah, dan Indeks Harga Saham Gabungan di Bursa Efek Jakarta.

Indeks Harga Saham Gabungan (IHSG) di Bursa Efek Jakarta merupakan gambaran secara umum harga saham yang go publik. Kenaikan atau penurunan IHSG harga saham yang go publik di Bursa Efek Jakarta. Saat ini, IHSG menjadi salah satu indikator penting yang menunjukan kondisi ekonomi Indonesia sehingga pergerakan naik turunya IHSG menarik untuk diamati. 


\section{Masalah}

Berdasarkan uraian tersebut, sangat menarik untuk mengetahui faktor yang mempengaruhi pergerakan IHSG. Faktor tersebut adalah suku bunga deposito, kurs ruapiah, dan harga emas. Oleh karena itu, pokok masalah dalam tulisan ini menjelaskan bagaimana pengaruh tingkat suku bunga deposito, kurs rupiah per dolar Amerika, dan harga emas terhadap IHSG di Bursa Efek Jakarta yang dirumuskan sebagai berikut.

1. Apakah tingkat suku bunga deposito berpengaruh terhadap IHSG.

2. Apakah kurs rupiah per dolar Amerika berpengaruh terhadap IHSG.

3. Apakah harga emas berpengaruh terhadap IHSG.

\section{Kerangka Pemikiran}

Saat ini, para investor cenderung buy and sale atau membeli saham untuk dijual kembali. Artinya, keuntungan yang diharapkan investor berasal dari capital gain bukan dari dividen. Untuk memperoleh capital again, investor harus dapat mengambil keputusan untuk membeli atau menjual sahamnya pada waktu yang tepat. Pada saat itulah masalah akan muncul karena sulit sekali untuk menentukan waktu yang tepat karena banyak variabel yang harus diperhatikan sebelum mengambil keputusan.

Investasi dalam saham, deposito, dolar Amerika, maupun membeli emas merupakan alternatif investasi. Oleh karena itu, dalam mengambil keputusan, salah satu investasi akan mempertimbangkan alternatif yang lain. Dengan demikian, IHSG sebagai indikator harga saham secara umum akan dipengaruhi oleh indikator harga investasi lainnya, seperti tingkat suku bunga deposito, kurs Rupiah terhadap Dolar Amerika, dan harga emas.

Berdasarkan penjelasan itu, patut diduga bahwa pergerakan harga saham yang tercermin dalam IHSG juga dipengaruhi oleh informasi mengenai alternatif investasi lain seperti tingkat bunga deposito, kurs rupiah terhadap Dolar Amerika, dan harga emas.

\section{Hipotesis}

Dalam penelitian ini, hipotesis yang dikemukakan seperti berikut.

1. Variabel bunga deposito diduga berpengaruh negatif terhadap IHSG.

2. Variabel kurs dolar Amerika berpengaruh negatif terhadap IHSG.

3. Variabel harga emas diduga mempunyai pengaruh negatif terhadap IHSG.

\section{Metodologi}

Untuk mengetahui pengaruh/hubungan tingkat suku bunga deposito, kurs RP/US\$, dan harga emas terhadap IHSG, digunakan alat analisis regresi berganda linier dengan persamaan berikut

$$
\mathrm{Y}=\mathrm{a}+\mathrm{b}_{1} \mathrm{X}_{1}+\mathrm{b}_{2}+\mathrm{b}_{3} \mathrm{X}_{3}+\mathrm{e}
$$

Y : IHSG

Penga ruh Bunga Deposito, Kurs mata Uang... (Guntur Iria nto) 
a : intercept

$\mathrm{X}_{1}$ : tingkat suku bunga deposito

$\mathrm{X}_{2}$ : kurs rupiah terhadap dolar Amerika

$\mathrm{X}_{3}$ : harga Emas

$\mathrm{B}_{\mathrm{n}}$ : koefisien regresi

Untuk melihat pengaruh variabel independen terhadap variabel dependen, secara parsial dilakukan uji t. Untuk mengetahui pengaruh variabel independen terhadap variabel dependen secara serentak dilakukan uji F. Perhitungan statistik menggunakan program SPSS 9.05 yang dijalankan melalui Windows 98.

\section{Variabel dan Indikatior}

Variabel dan indikator dalam penelitian ini sebagai berikut.

1. Variabel dependen adalah IHSG dengan indikator tingkat suku bunga deposito berjangka waktu satu bulan yang dijamin oleh pemerintah Indonesia yang dikeluarkan oleh Bank Indonesia secara harian.

2. Kurs Rupiah per dolar merika dengan indikator kurs tengah yang dikeluarkan Bank Indonesia secara harian.

3. Harga emas per gram dengan indikator harga jual emas murni (logam mulia) per 1 gram di Jakarta yang diproduksi PT Aneka Tambang secara harian.

\section{Data}

Dalam penelitian ini, data yang digunakan merupakan data sekunder periode 1 Juni 1998 sampai 30 Juni 2000 yang diperoleh dari berbagai sumber sebagai berikut.

\begin{tabular}{|c|c|}
\hline Jenis Data & Sumber Data \\
\hline $\begin{array}{l}\text { IHSG harian selama bulan Juni } 1998 \text { hingga } \\
\text { Juni } 2000\end{array}$ & Perpustakaan harian Bisnis Indonesia \\
\hline $\begin{array}{l}\text { Tingkat bunga deposito selama satu bulan yang } \\
\text { dijamin oleh pemerintah Indonesia untuk } \\
\text { periode bulan Juni } 1998 \text { sampai Juni } 2000\end{array}$ & $\begin{array}{l}\text { Bank Indonesia dan bagian treasury PT Bank } \\
\text { Agroniaga }\end{array}$ \\
\hline $\begin{array}{l}\text { Kurs rupiah persatu dolar Amerika selama } \\
\text { bulan Juni } 1998 \text { hingga Juni } 2000\end{array}$ & $\begin{array}{l}\text { Bank Indonesia dan perpustakaan harian Bisnis } \\
\text { Indonesia }\end{array}$ \\
\hline $\begin{array}{l}\text { Harga emas per satu gram selama bulan Juni } \\
1998 \text { sampai juni } 2000\end{array}$ & Perpustakaan harian Bisnis Indonesia \\
\hline
\end{tabular}




\section{PEMBAHASAN}

\section{Hasil Perhitungan}

Data input IHSG, bunga deposito, kurs Rp terhadap US\$, dan harga emas merupakan data periode bulan Juni 1998 sampai Juni 2000. Data itu diedit dengan membuang data yang kosong (karena adanya hari libur/hari raya) sehingga data net yang diperoleh sebanyak 509 pasang data dari total 730 hari kalender sejak Juni 1998 hingga Juni 2000 dengan rincian sebagai berikut.

Tabel 1 Data Input

\begin{tabular}{ccc}
\hline No. & Tahun & Jumlah Pasang Data \\
\hline 1 & 1998 & 145 pasang data \\
\hline 2 & 1999 & 247 pasang data \\
\hline 3 & 2000 & 117 pasang data \\
\hline & Jumlah & 509 pasang data \\
\hline
\end{tabular}

Data IHSG, bunga deposito, kurs Rp terhadap US\$, dan harga emas selama pengamatan dapat dilihat pada grafik berikut ini.

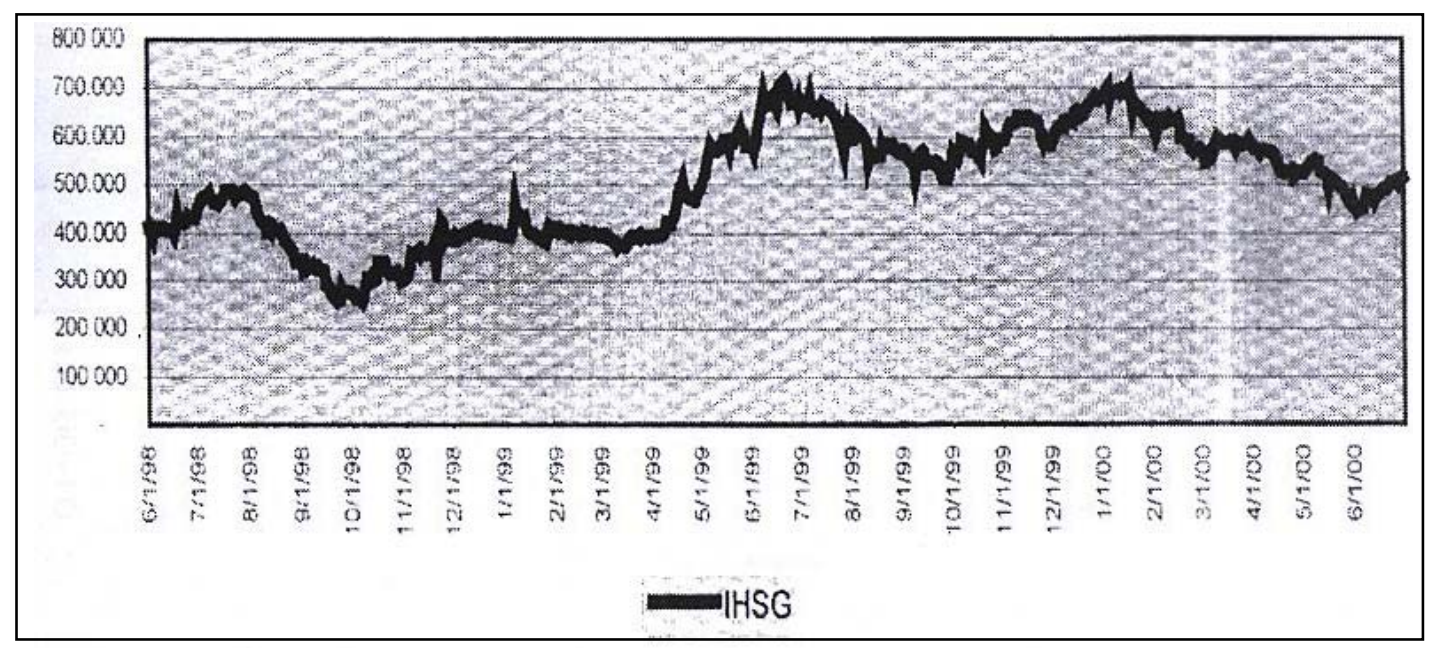

Gambar 1 Pergerakan Indeks Harga Saham Gabungan di BEJ (Closing Price)

Periode 1 Juni 1998 Hingga 30 Juni 2000

Pengaruh Bunga Deposito, Kurs mata Uang... (Guntur Iria nto) 


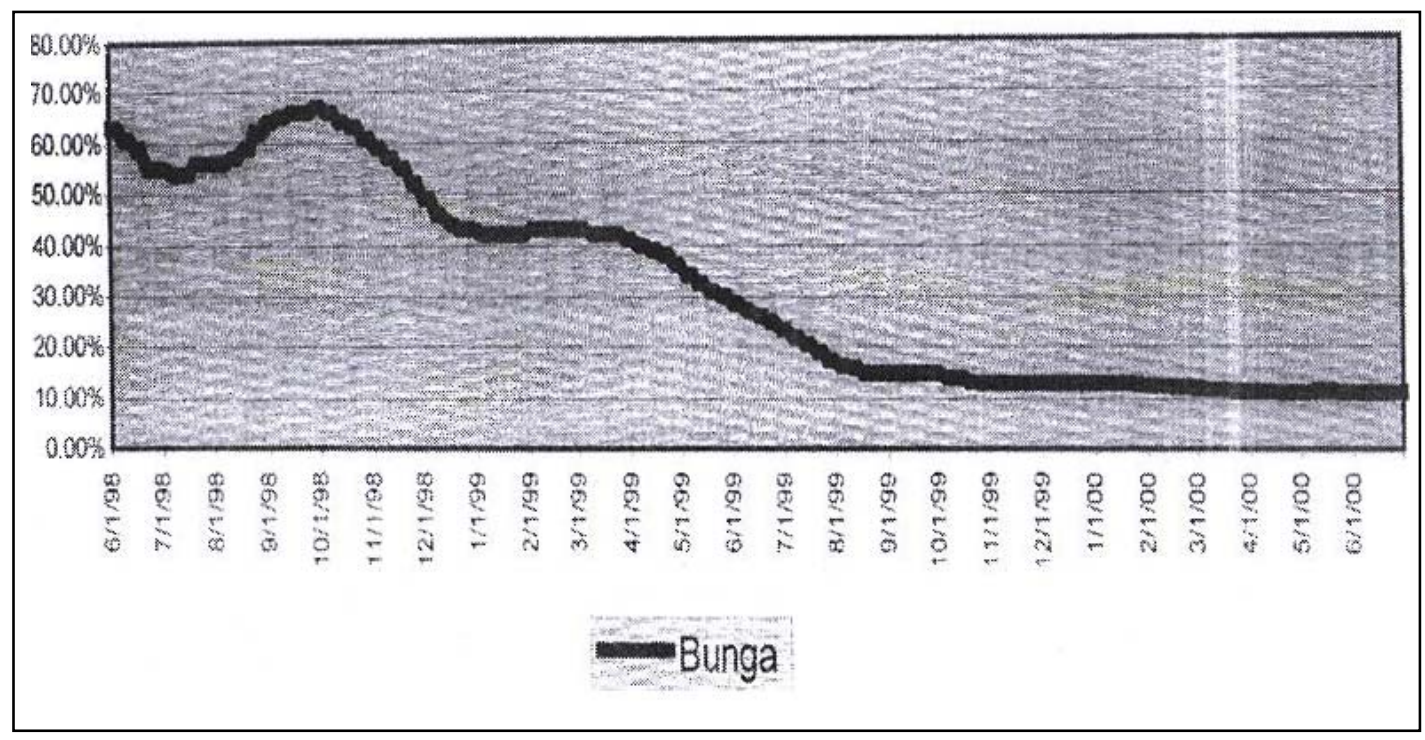

Gambar 2 Pergerakan Tingkat Bunga Deposito Jangka Waktu 1 Bulan Sesuai Jaminan Pemerintah RI Selama 1 Januari 1998 sampai 30 Juni 2000

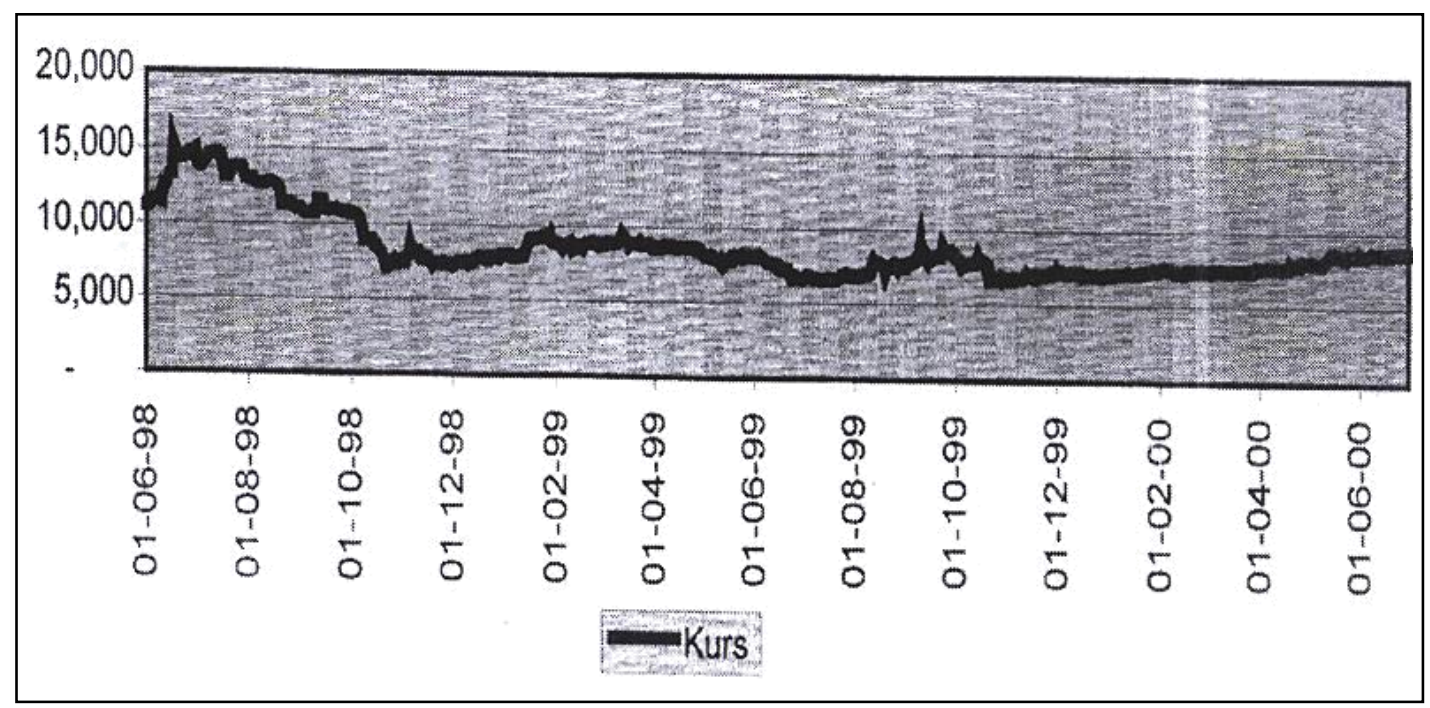

Gambar 3 Pergerakan Kurs Rupiah per Satu Dolar Amerika (Kurs Tengah Bank Indonesia) Periode 1 Juni 1998 hingga 30 Juni 2000

\section{Hasil Regresi}

Hasil regresi sebanyak 509 pasang data input dengan program SPSS 9.05 sebagai berikut. 
Tabel 2 Hasil Regresi Bunga Deposito, Kurs Rp/US\$, dan Harga Emas terhadap IHSG

\begin{tabular}{lcccc}
\hline \multicolumn{1}{c}{ Variabel } & Coef. Regresi & t hitung & F hitung & N = 509 \\
\hline Bunga & $-517,436$ & $-26,232$ & & $\alpha=5 \%$ \\
\hline Kurs & $-0,01933$ & $-2,917$ & 378,363 & $\mathrm{t}$ tabel $=2,4469$ \\
\hline Harga Emas & 0,0002289 & 3,528 & $\mathrm{f}$ tabel $=2,2622$ \\
\hline Constanta & 649,383 & 45,799 & $\mathrm{R}^{2}=69,2 \%$ \\
\hline
\end{tabular}

Dari perhitungan itu, diperoleh persamaan regresi sebagai berikut.

$\mathrm{Y}=649,383-517,436 \mathrm{X}_{1}-0,01933 \mathrm{X}_{2}+0,0002289 \mathrm{X}_{3}+\mathrm{e}$

$\mathrm{Y}=\mathrm{IHSG}$

$\mathrm{X}_{1}=$ Bunga Deposito

$\mathrm{X}_{2}=$ Kurs Rupiah

$\mathrm{X}_{3}=$ Harga Emas

Hasil regresi tersebut dapat diartikan seperti berikut.

1. Jika bunga deposito naik sebesar 1 satuan, IHSG akan turun sebesar 517,436 satuan atau sebaliknya dengan asumsi kurs Rp/US\$ dari harga emas tidak berubah.

2. Jikamkurs Rp/US\$ naik sebesar 1 satuan, IHSG akan turun sebesar 0,01933 satuan atau sebaliknya dengan asumsi bunga deposito dan harga emas tidak berubah.

3. Jika harga emas naik 1 satuan, IHSG akan naik sebesar 0,0002289 satuan atau sebaliknya dengan sumsi bunga deposito dan kurs Rp/US\$ tidak berubah.

\section{Koefisien DeterminasI $\left(\mathbf{R}^{2}\right)$}

Hasil perhitungan Tabel 1 menunjukan nilai $\mathrm{R}^{2}$ sebesar 69,2\%. Artinya 69,2\% perubahan variabel dependen $\mathrm{Y}$ (IHSG) disebabkan oleh perubahan variabel independen $\mathrm{X}_{1}$ (bunga deposito), $\mathrm{X}_{2}$ (kurs Rp/US\$), dan $\mathrm{X}_{3}$ (harga emas) secara bersama - sama. Sisanya sebesar 30,8\% dipengaruhi oleh variabel lain yang tidak termasuk dalam model.

\section{Uji Koefisien Regresi}

Pada matriks hasil regresi terlihat bahwa t hitung koefisien $X_{1}$ sebesar -26,232; $t$ hitung koefisien $\mathrm{X}_{2}$ sebesar $-2,917$ dan $\mathrm{t}$ hitung koefisien $\mathrm{X}_{3}$ sebesar 3,528 sedangkan $\mathrm{t}$ tabel ${ }_{(0,05 ; 505)}=$ 2,4469. Karena semua t hitung lebih besar dari t tabel, dapat dikatakan bahwa koefisien variabel bunga deposito, kurs Rp/US\$, dan harga emas secara signifikan dari masing-masing variabel dependen (IHSG) secara individu. 
Pada matriks hasil regresi terlihat bahwa $\mathrm{F}$ hitung $=378,363$ yang lebih besar dari $\mathrm{F}$ tabel $(0,05 ; 3 ; 505)=2,6226$. Dengan demikian, terdapat pengaruh yang signifikan dari variabel independen (bunga deposito, kurs Rp/US\$, dan harga emas secara bersama-sama. Dari hasil uji koefisien regresi, dapat disimpulkan sebagai berikut.

1. Terdapat pengaruh yang signifikan atau $69,2 \%$ perubahan IHSG dipengaruhi oleh bunga deposito, kurs Rp/US\$, dan harga emas secara bersama - sama.

2. Bunga deposito mempunyai pengaruh negatif terhadap IHSG.

3. Harga emas memiliki pengaruh positif terhadap IHSG.

Hasil regresi dan pengujian menyimpulkan variabel independen bunga deposito dan kurs Rp/US\$ memiliki pengaruh negatif secara signifikan terhadap variabel dependen IHSG. Di lain pihak, variabel independen harga emas mempunyai pengaruh positif terhadap variabel dependen IHSG.

\section{Pengaruh Negatif Bunga Deposito terhadap IHSG}

Pengaruh negatif bunga deposito terhadap IHSG artinya jika bunga deposito naik, IHSG atau harga saham secara umum akan turun. Sebaliknya jika bunga deposito turun, IHSG atau harga saham secara umum akan naik. Keadaan tersebut terkondisi karena preferensi investor dalam memilih investasiya agar dapat mengoptimalkan hasil. Hubungan antara investasi dalam saham dan deposito bersifat subtitusi.

Jika perbankan mengumumkan bunga deposito naik dan cukup signifikan, sebagian besar investor dalam saham akan berpaling menginvestasikan uangnya pada deposito. Naiknya suku bunga deposito itu mendorong terjadinya aksi jual saham karena akan dialihkan pada deposito. Selama investor menganggap investasi deposito masih menguntungkan (asumsi investor sudah mempertimbangkan aspek risiko), akan terus terjadi aksi jual saham itu mengakibatkan harga saham akan turun karena penawaran saham meningkat. Jika harga saham turun, IHSG pun akan turun.

Aksi jual saham akan berhenti apabila perbankan menurunkan kembali bunga deposito pada tingkat keseimbangan. Penurunan tingkat deposito akan dilakukan perbankan jika dana dari pihak ketiga sudah melampaui kebutuhan penyaluran kredit. Jika perbankan tidak menurunkan buga deposito, dana pihak ketiga yang tidak tersalurkan dalam kredit semakin besar, artinya cost of money setiap uang yang dipinjamkan semakin besar.

Jika perbankan melakukan penurunan bunga deposito, investor deposito akan berpaling pada investasi saham. Dengan kata lain, investor deposito akan mencairkan depositonya dan segera membeli saham. Makin banyak investor membeli saham, permintaan dan harga saham maupun IHSG juga meningkat.

\section{Pengaruh Negatif Kurs RP/US\$ terhadap IHSG}

Pengaruh positif harga emas terhadap IHSG terjadi jika harga emas naik, IHSG secara umum akan naik juga. Sebaliknya jika harga emas turun, IHSG secara umum akan turun juga. Variabel harga emas itu berbeda dengan variabel bunga deposito dan kurs Rp/US\$. Artinya, hubungan antara investasi dalam saham dan pembelian emas tidak bersifat subtitusi karena 
masyarakat tidak menganggap pembelian emas sebagai alternatif investasi tetapi lebih bersifat konsumtif.

Harga emas dalam analisis ini merupakan harga emas batangan. Harga emas batangan tersebut terbentuk karena mekanisme pasar termasuk pasar umum bagi masyarakat secara luas. Tujuan masyarakat luas dalam membeli emas lebih bersifat untuk perhiasan dan bukan untuk tujuan investasi. Oleh karena itu, antara investasi dalam saham dan pembelian emas tidak bersifat subtitusi sehingga pengaruh harga emas terhadap IHSG tidak negatif sebagaimana hipotesis yang telah di kemukakan. Untuk mengungkap mengapa harga emas berpengharuh positif terhadap IHSG, perlu penelitian lebih lanjut.

\section{PENUTUP}

\section{Simpulan}

Dari hasil analisis penelitian secara keseluruhan, dapat diambil simpulan sebagai berikut.

1. Perubahan pada tingkat suku bunga deposito yang dijamin oleh pemerintah akan mempengaruhi IHSG secara negatif. Hal itu disebabkan adanya preferensi investor untuk mengoptimalkan investasinya karena antara investasi pada saham dan deposito bersifat subtitusi.

2. Perubahan atas tingkat kurs Rp/US\$ akan mempengaruhi IHSG secara negatif. Hal tersebut disebabkan adanya preferensi investor untuk mengoptimalkan investasinya karena antara investasi pda saham dan US\$ bersifat subtitusi.

3. Perubahan atas harga emas akan mempengaruhi IHSG secara positif dan tidak negatif. Hal tersebut karena pembelian emas oleh masyarakat bukan bermotif investasi tetapi bermotif konsumtif untuk perhiasan. Jadi, hubungan investasi pada saham dan pembelian emas bersifat subtitusi.

4. Perlu penelitian dan kajian lebih lanjut mengapa harga emas berpengaruh positif terhadap IHSG.

5. Tingkat bunga deposito dan kurs Rp/US\$ dapat dijadikan sebagai bahan analisis keputusan investasi dalam saham.

\section{DAFTAR PUSTAKA}

Algifari. 1997. Analisis Statistik untuk Bisnis. Edisi Pertama. Yogyakarta: BP-FE.

Anonim. 1995. Undang-Undang Republik Indonesia No. 8 Tahun 1995 tentang Pasar Modal. Jakarta.

F. Stoner, James. 1982. Management. Second Edition. New York: Prentice Hall Inc.

Helfert, Erich. 1994. Teknik Analisis Keuangan. Petunjuk praktis untuk Mengelola dan Mengukur Kinerja perusahaan, terj. Herman Wibowo. Jakarta: Erlangga. 
Higgins, Robert C. 1989. Analisis Keuangan, terj. Gunawan. Edisi 2. Jakarta: PT Indira.

Husnan, Suad. 1998. Dasar-Dasar Teori Portofolio dan Analisis Sekuritas. Edisi Tiga. Yogyakarta: UPP-AMP YKPN.

Karnadi, Steve. 1993. Manajemen Pembelanjaan. Yayasan Promotion Humania Edisi Kedua. Jakarta.

Santoso, Singgih. 1999. SPSS (Statistical Product and Service Solutions)-Mengolah Data Statistik Secara Profesional. Jakarta: PT Elex Media Komputindo.

Supranto, J. 1991. Teknik Pengambilan Keputusan. Edisi Pertama. Jakarta: PT Rineka Cipta. 1989. Metode Riset Aplikasi. Jakarta: LP-FE UI.

Scott. 1993. Analisis Pasar Modal. Jakarta: Pustaka Sinar Harapan.

Sharpe, William F., Gordon A., dan Jeffery V. Baikey. 1995. Investasi, terj. Henry Njoooiangtik et al. Jakarta: PT Prenhalindo.

Usman, Marzuki. 1990. “ABC Pasar Modal”. Kerjasama Lembaga Pengembangan Perbankan Indonesia dengan Ikatan Sarjana Ekonomi Indonesia, Jakarta. 1982. Metodologi Riset. Edisi Revisi. Yogyakarta: BP-FE UI. 1997. Pengetahuan Dasar Pasar Modal. Jakarta: IBI.

Weston J, Fred dan Brigham Eugene F. 1998. Dasar-Dasar Manajemen Keuangan, terj. Alfons Sirait. Jakarta: Erlangga.

dan Thomas E. Copeland. 1986. Manajemen Keuangan, terj. Kirbrandoko et al. Edisi 8. Jakarta: Erlangga. 